\title{
LEMBAGA TUNGGAL PENGELOLA REGULASI: DASAR PEMIKIRAN DAN TAWARAN IMPLEMENTASINYA DALAM KETATANEGARAN INDONESIA
}

\author{
Rilo Pambudi. S \\ Magister Ilmu Hukum, Universitas Gadjah Mada \\ e-mail: rilopambudis@mail.ugm.ac.id \\ Oksep Adhayanto \\ Program Studi Ilmu Hukum, Universitas Maritim Raja Ali Haji \\ e-mail: adhayantooksep@umrah.ac.id \\ Pery Rehendra Sucipta \\ Program Studi Ilmu Hukum, Universitas Maritim Raja Ali Haji \\ e-mail: peryrehsucipta@umrah.ac.id
}

disampaikan 10/09/2020 - di-review 15/10/2020 - diterima 02/11/2021

DOI: $10.25123 /$ vej.v7i2.4237

\begin{abstract}
In this article the author seeks to answer, within the context of the Indonesia state organizational system, why and how Indonesia should establish a single government authority entrusted with supervising the making of ministerial policy regulations or regional government regulations. To that purpose a comparison with other countries is conducted. It is a fact in Indonesia that regulatory powers or function is shared by and among different ministries and by regional governments. The result of which is the problem of sectoral approach and the existence of numerous overlapping and conflicting regulations. To overcome this problem, in consideration of best practices in other countries, the author suggests the establishment of a single government agency entrusted with, inter alia, previewing ministerial or regional government draft regulations.
\end{abstract}

Keywords:

Single government regulatory agen; ministerial-regional government policy regulations; executive preview;

\begin{abstract}
Abstrak
Penulis akan menelusuri alasan-pertimbagan hukum yang ada di Indonesia untuk membentuk lembaga tunggal pengelola regulasi dalam sistem ketatanegaraan Indonesia. Untuk itu juga akan dilakukan perbandingan hukum dengan negara-negara lain. Dalam kenyataan dapat ditunjukkan bahwa fungsi pembentukan regulasi ternyata tersebar di berbagai kementerian atau lembaga pemerintahan dan pemerintahan daerah. Akibatnya adalah tumbuh kembangnya regulasi yang cenderung sangat sektoral. Selain itu, kerap terjadi adanya banyak regulasi diterbitkan lembaga berbeda-beda yang tumpang tindih dan tidak selaras satu sama lain. Solusi yang ditawarkan, dengan membandingkan praktik baik negara-negara lain adalah perlunya membentuk sekretarian perundang-undangan yang memiliki antara lain kewenangan melakukan executive preview, khususnya berkenaan dengan keberagaman peraturan daerah.
\end{abstract}

Kata Kunci:

Lembaga tunggal pengelola regulasi; aturan kebijakan kementerian-peraturan daerah; executive preview; 


\section{Pendahuluan}

Dewasa ini, terjadi suatu kecenderungan oleh pemerintah untuk menjadikan pembentukan regulasi ${ }^{1}$ sebagai obat paling ampuh dalam mengatasi setiap permasalahan bangsa dan negara. ${ }^{2}$ Dalam perkembangannya, kecenderungan tersebut menjadi tidak terkendali dan menyebabkan kuantitas regulasi kian menggemuk. Kondisi ini disebut Richard Susskind sebagai hyperregulation $^{3}$ atau yang kemudian populer disebut obesitas hukum ${ }^{4}$. Data dari Kementerian Hukum dan HAM RI $^{5}$ (Kemenkumham) menunjukkan bahwa terhitung April 2021, Indonesia telah memiliki 44.355 aturan yang terdiri dari berbagai jenis regulasi seperti terlihat pada tabel berikut:

\section{Tabel 1: Jumlah Regulasi di Indonesia Tahun 1945-2021}

\begin{tabular}{|c|c|c|}
\hline No. & Jenis Regulasi & Jumlah \\
\hline 1 & Undang-Undang & 1.699 \\
\hline 2 & Peraturan Pemerintah Pengganti Undang-Undang & 182 \\
\hline 3 & Peraturan Pemerintah & 4.652 \\
\hline 4 & Peraturan Presiden & 2.154 \\
\hline 5 & Peraturan Menteri & 15.579 \\
\hline 6 & Peraturan Lembaga Pemerintah Non-Kementerian & 4.107 \\
\hline 7 & Peraturan Daerah (Provinsi dan Kabupaten/Kota) & 15.982 \\
\hline
\end{tabular}

1 Regulasi yang dimaksudkan mengacu pada Pasal 1 angka 1 Undang-Undang Nomor 15 Tahun 2019 Tentang Perubahan Atas Undang-Undang Nomor 12 Tahun 2011 Tentang Pembentukan Peraturan Perundang-undangan, yakni "peraturan tertulis yang memuat norma hukum yang mengikat secara umum dan dibentuk atau ditetapkan oleh lembaga negara atau pejabat yang berwenang melalui prosedur yang ditetapkan dalam peraturan perundang-undangan."

2 Ibnu Sina Chandranegara, Menemukan Formulasi Diet Regulasi, dalam Prosiding Konferensi Nasional Hukum Tata Negara Ke-4: Penataan Regulasi di Indonesia, Jember, UPT Penerbitan Universitas Jember, 2017, hlm., 215.

3 Richard Susskind kemudian menjabarkannya sebagai "By that I meant we are all governed today by a body of rules and laws that are so complex and so large in extent that no one can pretend to have mastery of them all. I argued then that hyper-regulation means not that there is too much law, by some objective standard, but that there is too much law given our current methods of managing it." Dalam pandangannya, obesitas hukum terjadi karena begitu banyak metode pengelolaan regulasi yang diberlakukan. Lihat Richard Susskind, Legal Informatics - a Personal Appraisal of Context and Progress, European Journal of Law and Technology, Vol. 1, No. 1, Juni 2010, hlm., 90.

4 Istilah ini berkembang dalam Focus Group Discussion "Penyusunan Program dan Strategi Reformasi Regulasi dalam Rangka Memperkuat Substansi dan Operasionalisasi UU No. 12 Tahun 2011" yang digagas oleh Kementerian Hukum dan HAM di Bogor pada tanggal 26-28 Oktober 2016. Lihat catatan kaki nomor 2 dalam Ibnu Sina Ch andranegara, Bentuk-Bentuk Perampingan dan Harmonisasi Regulasi, Jurnal Hukum Ius Quia Iustum, Vol. 26, No. 3, September 2019, hlm., 436.

5 Kementerian Hukum dan HAM RI, http://peraturan.go.id, diakses 27 April 2021.

6 Id. 
Permasalahan obesitas hukum tersebut diperburuk pula dengan persoalan kualitas regulasi yang masih rendah. Menteri Hukum dan HAM, Yasona H. Laoly mengatakan rendahnya kualitas regulasi di Indonesia ditandai dengan adanya ketidakharmonisan antar peraturan, tumpang tindih, dan banyaknya regulasi yang tidak efektif.7 Senada dengan hal itu, Diani Sadiawati, et al., menyebutkan setidaknya ada 4 (empat) bentuk permasalahan implementasi regulasi di Indonesia, yaitu konflik materi muatan ${ }^{8}$, inkonsisten ${ }^{9}$, multitafsir ${ }^{10}$, dan tidak operasional ${ }^{11}$.

Kedua persoalan ini sejatinya telah berulang kali mendapat sorotan dari berbagai pihak. Misalnya Diani Sadiawati, et al., yang menilai permasalahan regulasi tersebut terjadi sebagai konsekuensi dari kegagalan dalam mendesain kelembagaan yang memegang peranan untuk mengelola regulasi. ${ }^{12}$ Akar persoalan terkait desain kelembagaan pengelola regulasi yang kerap kali disorot adalah ketiadaaan lembaga yang mempunyai kontrol penuh terhadap fungsi pengelolaan regulasi dari hulu hingga ke hilir. Kewenangan pembentukan regulasi tersebut terpencar pada kementerian/lembaga ${ }^{13}$, misalnya di unit Eselon I atau Eselon II di Kemenkumham, Kementerian Dalam Negeri, Kementerian Sekretariat Negara, dan Sekretariat Kabinet.14 Belum lagi jika bicara tentang Peraturan

7 M. Dani Pratama Huzaini, Akui Kualitas Produk Legislasi Rendah, Pemerintah Fokus Harmonisasi Regulasi, https://www.hukumonline.com/berita/baca/lt59f13bb6e2702/akuikualitas-produk-legislasi-rendah--pemerintah-fokus-harmonisasi-regulasi\%0D, diakses 27 April 2021.

8 Konflik muatan materi terjadi apabila pasal atau ketentuan yang nyata-nyata bertentangan dengan peraturan lainnya. Diani Sadiawati, et al., Strategi Nasional Reformulasi Regulasi, Jakarta, Bappenas, 2015, hlm., 38.

9 Regulasi dinyatakan inkonsisten ketika terdapat ketentuan atau pengaturan yang tidak konsisten dalam satu peraturan perundang-undangan beserta turunannya. Id.

10 Multitafsir berkaitan dengan ketidakjelasan pada objek dan subjek yang diatur sehingga menimbulkan ketidakjelasan rumusan bahasa (sulit dimengerti) serta sistematika yang tidak jelas. Id, hlm., 39.

11 Regulasi yang dibentuk tidak memiliki daya guna, namun peraturan tersebut masih berlaku atau peraturan tersebut belum memiliki peraturan pelaksana. Id.

12 Id, hlm., 45.

13 Id.

14 PSHK, 2020, Menagih Janji Jokowi Membentuk Badan Legislasi Pemerintahan, https://pshk.or.id/rr/menagih-janji-jokowi-membentuk-badan-legislasi-pemerintahan/, diakses 27 April 2021. 
Menteri dan Peraturan Lembaga Pemerintah Non-Kementerian (LPNK), dimana pengelolaannya berada pada institusi masing-masing.

Realitas semacam ini memunculkan gagasan dalam debat Capres dan Cawapres pada 17 Januari 2019, pasangan calon Joko Widodo dan Ma'ruf Amin, menyatakan perlu dilakukan penataan kelambagaan dengan membentuk Pusat Legislasi Nasional. ${ }^{15}$ Melalui lembaga ini, fungsi-fungsi legislasi selain yang ada di parlemen akan digabungkan. Lebih lanjut jika terbentuk, lembaga tunggal pengelola regulasi tersebut akan mengambil peran untuk menyederhanakan aturan, memastikan harmonisasi regulasi, dan menyelesaikan tumpang tindih peraturan. ${ }^{16}$

Gagasan ini sebenarnya sudah pernah direkomendasikan oleh Organisation for Economic Co-operation and Development (OECD) pada tahun 2012. Dalam laporannya, OECD menilai Indonesia perlu membentuk lembaga independen yang berwenang mengambil keputusan pembentukan regulasi berdasarkan bukti dan koordinasi dengan lembaga-lembaga lain dalam pemerintah. ${ }^{17}$

Selanjutnya, wacana pembentukan lembaga tunggal regulasi menjadi diskursus hangat di Indonesia. Intensitas diskursus itu mencapai puncak dengan disahkannya Undang-Undang Nomor 15 Tahun 2019 Tentang Perubahan Atas Undang-Undang Nomor 12 Tahun 2011 Tentang Pembentukan Peraturan Perundang-undangan (UU PPP). Muatan materi UU PPP ini mengatur dasar pembentukan lembaga tunggal pengelola regulasi yang disebut dengan "kementerian atau lembaga yang menyelenggarakan urusan pemerintahan di bidang pembentukan peraturan perundang-undangan."18

Meskipun secara faktual kementerian atau lembaga tersebut belum ada, tetapi eksistensinya secara yuridis telah menyita atensi masyarakat luas,

15 Kompas.com, Atasi Tumpang Tindih Regulasi, Jokowi Akan Bentuk Pusat Legislasi Nasional, https://nasional.kompas.com/read/2019/01/17/21041881/atasi-tumpang-tindih-regulasijokowi-akan-bentuk-pusat-legislasi-nasional, diakses 27 April 2021.

16 Id.

17 OECD, Reviews of Regulatory Reform Indonesia: Government Capacity to Assure High Quality Regulation, Paris, OECD, 2012, hlm., 46.

18 Lihat Pasal 99A Undang-Undang Nomor 15 Tahun 2019 Tentang Perubahan Atas UndangUndang Nomor 12 Tahun 2011 Tentang Pembentukan Peraturan Perundang-undangan, Lembaran Negara RI Tahun 2019 Nomor 183, Tambahan Lembaran Negara RI Nomor 6398. 
khususnya dari kalangan akademisi hukum. Salah satu diskursus yang substansial adalah terkait konstruksi kelembagaannya, baik dari segi tipe, kewenangan, maupun stuktur kelembagaannya. Untuk itu, tulisan ini pada dasarnya bertujuan menjawab dua isu utama, yaitu apa yang menjadi dasar pemikiran dibentuknya lembaga tunggal pengelola regulasi. Lantas jika dibentuk, bagaimana konstruksi kelembagaan yang dapat ditawarkan untuk digunakan, mengingat UU PPP belum mengaturnya secara komprehensif. Tawaran ini akan fokus pada tipe, kewenangan, dan struktur kelembagaan.

Untuk menjawab isu di atas, penulis menggunakan metode penelitian hukum normatif (library research), yaitu penelitian yang mengkaji suatu studi dokumen yang mana menggunakan data sekunder yang mempunyai kaitan dengan permasalahan. ${ }^{19}$ Pendekatan yang digunakan adalah statute approach, conceptual approach, dan comparative approach. Perpaduan beberapa pendekatan ini tentunya berpijak pada pernyataan Enid Cambell dan E. J. Glasson bahwa "there is no single technique that is magically right for all problem." 20 Sumber data terdiri dari bahan hukum primer, bahan hukum sekunder, dan bahan hukum tersier dengan teknik pengumpulan datanya berupa studi kepustakaan. Data-data tersebut kemudian dianalisis secara kualitatif dengan alur berpikir deduktif, sehingga mendapatkan kesimpulan yang bersifat khusus.

\section{Pembahasan}

\section{Dasar Pemikiran Pembentukan Lembaga Tunggal Pengelola Regulasi di Indonesia}

Sesungguhnya spirit untuk membentuk lembaga tunggal yang khusus menangani pembentukan regulasi di Indonesia sudah ada sejak era Presiden Soekarno. Masa itu, Presiden Soekarno telah merancangnya melalui penerbitan Peraturan Presiden Nomor 6 Tahun 1964 Tentang Panitia Negara Badan Perencanaan Pembangunan Nasional Urusan Tata-Cara dan Peraturan Perundang-

19 Johnny Ibrahim, Teori Dan Metodologi Penelitian Hukum Normatif, Malang, Bayumedia Publishing, 2006, hlm., 295.

20 Oksep Adhayanto, Eksistensi Hak Preogratif Presiden, Tanjungpinang, UMRAH Press, 2015, hlm., 25. 
Undangan. Namun harus disayangkan, peraturan ini tidak mampu dioperasionalkan karena adanya pergantian kekuasaan. ${ }^{21}$

Ide serupa kembali muncul pada debat pertama Capres dan Cawapres tanggal 17 Januari 2019. Capres nomor urut 1, Joko Widodo menjanjikan jika terpilih kembali, ia akan membentuk Pusat Legislasi Nasional yang menggabungkan fungsi-fungsi legislasi yang ada di kementerian. ${ }^{22}$ Selanjutnya, gagasan ini direspon positif oleh M. Nur Sholikin, peneliti senior Pusat Studi Hukum dan Kebijakan Indonesia (PSHK). Ditegaskan olehnya, eksistensi lembaga tunggal ini amat penting untuk mengatasi beragam tumpang tindih aturan dan tidak terintegrasinya fungsi-fungsi manajemen penyusunan regulasi di pemerintahan. ${ }^{23}$

Apabila ditelaah lebih jauh, munculnya ide untuk membentuk lembaga tunggal regulasi di Indonesia dilatarbelakangi oleh beberapa dasar pemikiran. Adapun dasar pemikiran tersebut yaitu: Pertama, ditinjau dari pengaturan kelembagaan pembentuk regulasi berdasarkan Undang-Undang Nomor 12 Tahun 2011 Tentang Pembentukan Peraturan Perundang-undangan. Dimana UU ini menempatkan fungsi-fungsi pembentukan regulasi tersebar di berbagai kementerian. Bahkan setiap kementerian memiliki keleluasaan dalam membentuk dan mengusulkan regulasi. ${ }^{24}$ PSHK menambahkan bahwa desain kelembagaan yang berlaku hari ini bersifat estafet kelembagaan. ${ }^{25}$ Setiap institusi mempunyai bagian atau wewenang masing-masing tetapi tidak bisa saling membantu. Alhasil, masing-masing institusi tersebut saling menunggu giliran, tidak bisa saling mendahului, dan terikat oleh proses. ${ }^{26}$

Pengaturan semacam ini menyulitkan pemerintah untuk memastikan terjadinya keselarasan antara perencanaan pembentukan regulasi dan

21 Diani Sadiawati, et al., Supra no. 8, hlm., 46.

22 Supra no 15

23 Supra no 14

24 M. Nur Sholikin, Penataan Kelembagaan Untuk Menjalankan Reformasi Regulasi di Indonesia, Jurnal Hukum dan Pasar ModalI, Vol. VIII, No. 15, 2018, hlm., 86.

25 Pusat Studi Hukum dan Kebijakan Indonesia, Prosiding Forum Akademik Kebijakan Reformasi Regulasi 2019: Menggagas Arah Kebijakan Reformasi Regulasi di Indonesia, Jakarta, Yayasan Studi Hukum dan Kebijakan Indonesia, 2019, hlm., 397.

26 Id. 
perencanaan pembangunan. Sebagai contoh adanya pemisahan skema institusi antara program penyusunan peraturan pemerintah dan peraturan presiden (Progsun PP dan Perpres) dengan Rencana Kerja Pemerintah (RKP). Di satu sisi, Progsun PP dan Perpres dikoordinasikan oleh Kemenkumham dan di sisi lainnya, Badan Perencanaan Pembangunan Nasional (Bappenas) bertanggung jawab atas penyusunan RKP. ${ }^{27}$ Pemisahan skema institusi ini sering kali mengakibatkan keduanya menjadi tidak sinkron. Indikasi ketidaksinkronan ini ditunjukkan sejak awal penyusunan dokumen perencanaan dengan melihat indikator waktu penyusunannya. Misalnya Penyusunan RKP untuk tahun 2019 telah dimulai sejak November 2017 dan akan ditetapkan pada tahun 2018.28 Adapun Progsun PP dan Perpres untuk tahun yang sama baru akan disusun pada akhir 2018 dan ditetapkan di awal 2019.29 Perbedaan rentang waktu tersebut mengakibatkan tidak bertemunya antara kebutuhan regulasi dengan prioritas pembangunan nasional. ${ }^{30}$

Kedua, pembentukan regulasi yang berlangsung saat ini masih mengedepankan pendekatan sektoral ketimbang pendekatan sistem. Model pendekatan tersebut mengakibatkan kuantitas regulasi terus meningkat dan akhirnya menciptakan obesitas hukum. Terhadap hal ini, Saldi Isra mengatakan bahwa fenomena hiper-regulasi yang terjadi di Indonesia terjadi pada level di bawah undang-undang. ${ }^{31}$ Secara tegas, ia mengatakan sumber masalah yang paling utama adalah peraturan menteri.

Mengulas data regulasi pada Tabel 1 membuktikan bahwa apa yang disampaikan Saldi Isra adalah fakta yang tidak dapat dibantah. Data tersebut menunjukkan bahwa kurun waktu 1945-2021 terdapat 15.579 peraturan menteri yang dibentuk. Angka ini ini jauh melebihi jumlah undang-undang, PP, bahkan

27 Diani Sadiawati, et al., Kajian Reformasi Regulasi di Indonesia: Pokok Permasalahan dan Strategi Penanganannya, Jakarta,Yayasan Studi Hukum dan Kebijakan Indonesia, 2019, hlm., 20.

28 Hendra Wahanu Prabandani, Rekonstruksi Mekanisme Perencanaan Pembentukan Peraturan Pemerintah dan Peraturan Presiden di Indonesia, Undang: Jurnal Hukum, Vol. 1, No. 1, Juni 2018, hlm., 96.

29 Id.

30 Id.

31 Saldi Isra, Merampingkan Regulasi, Jakarta, Koran Kompas, 13 Maret 2017, hlm., 5. 
Perpres pada periode yang sama. Membludaknya jumlah peraturan menteri dikarenakan secara hukum, ruang pembentukan peraturan menteri sangat terbuka lebar. ${ }^{32}$ Selain atas perintah regulasi yang lebih tinggi, peraturan menteri juga dapat dibentuk berdasarkan kewenangan. ${ }^{33}$ Kemudian Saldi Isra mencontohkan, pada tahun 2000-2015, jajaran eksekutif telah menerbitkan 12.471 regulasi dan 8.311 di antaranya merupakan peraturan menteri. ${ }^{34}$

Selanjutnya jika ditinjau dari perspektif yuridis, persoalan hiper-regulasi tidak hanya berkaitan dengan membengkaknya kuantitas regulasi, tetapi juga diakibatkan banyaknya jenis dan hierarki regulasi. Ketentuan Pasal 7 ayat (1) Undang-Undang Nomor 12 Tahun 2011 Tentang Pembentukan Peraturan Perundang-undangan menentukan 7 (tujuh) jenis regulasi, di antaranya: UndangUndang Dasar Negara Republik Indonesia Tahun 1945; Ketetapan Majelis Permusyawaratan Rakyat; Undang-Undang/Peraturan Pemerintah Pengganti Undang-Undang; Peraturan Pemerintah; Peraturan Presiden; Peraturan Daerah Provinsi; dan Peraturan Daerah Kabupaten/Kota.

Selain jenis dan hierarki di atas, Indonesia juga mengenal jenis regulasi lain yang diatur dalam ketentuan Pasal 8 ayat (1) Undang-Undang Nomor 12 Tahun 2011 yang berbunyi:

Jenis Peraturan Perundang-undangan selain sebagaimana dimaksud dalam Pasal 7 ayat (1) mencakup peraturan yang ditetapkan oleh Majelis Permusyawaratan Rakyat, Dewan Perwakilan Rakyat, Dewan Perwakilan Daerah, Mahkamah Agung, Mahkamah Konstitusi, Badan Pemeriksa Keuangan, Komisi Yudisial, Bank Indonesia, Menteri, badan, lembaga, atau komisi yang setingkat yang dibentuk dengan Undang-Undang atau Pemerintah atas perintah Undang-Undang, Dewan Perwakilan Rakyat Daerah Provinsi, Gubernur, Dewan Perwakilan Rakyat Daerah Kabupaten/Kota, Bupati/Walikota, Kepala Desa atau yang setingkat.

Faktanya, jumlah kementerian, badan, lembaga, atau komisi yang setingkat kementerian tidaklah sedikit. Untuk kementerian saja jumlahnya mencapai 34.

Id.

33 Lihat Pasal 8 ayat (2) Undang-Undang Nomor 12 Tahun 2011 Tentang Pembentukan Peraturan Perundang-undangan, Lembaran Negara RI Tahun 2011 Nomor 82, Tambahan Lembaran Negara RI Nomor 5234.

$34 \quad$ Saldi Isra, Supra no 31 
Lalu ada pula LPNK yang hingga tahun 2013 berjumlah 27 LPNK. ${ }^{35}$ Ditambah kehadiran Lembaga Non-Struktural (LNS) yang mencapai 135 lembaga. ${ }^{36}$ Lembaga-lembaga yang sedemikian banyaknya dengan eksistensi yang mengalami pertumbuhan, celakanya selalu dilekati dengan kewenangan untuk membentuk regulasi. Dengan demikian dapat dipahami, jenis dan jenjang regulasi di Indonesia selaras dengan banyaknya jenis tindakan pemerintah dalam kaitannya membentuk peraturan.

Ketiga, adanya tumpang tindih, disharmonisasi, dan ketidaksinkronan regulasi yang menyebabkan ketidakpastian hukum dan hilangnya benang merah politik hukum yang telah ditetapkan sebelumnya. ${ }^{37}$ Lebih jauh disadari dapat menghambat percepatan pembangunan dan peningkatan kesejahteraan masyarakat. Contohnya menghambat kemudahan dalam berusaha (ease of doing business). Hal ini diperkuat oleh laporan World Economic Forum tentang The Global Competitiveness Report 2019. Laporan tersebut menyebutkan, beban regulasi dari pemerintah (burden of government regulation) terhadap kemudahan berusaha di Indonesia berada pada skor 4,0 dari skala 1-7.38 PSHK menilai, skor tersebut mengindikasikan bahwa para pelaku bisnis di Indonesia masih diberatkan oleh persyaratan-persyaratan administrasi yang harus dipenuhi, termasuk alur birokrasi yang panjang dan bertele-tele, inefisiensi waktu, dan lain sebagainya. ${ }^{39}$

Sebelumnya, Presiden Jokowi melalui Bappenas telah meluncurkan Strategi Nasional Reformasi Regulasi Jangka Panjang 2015-2025 sebagai reaksi untuk memperbaiki kondisi tersebut. Dalam strategi itu, pemerintah menargetkan indikator burden of government regulation untuk tahun 2019 mencapai angka

35 Pusat Kajian Kinerja Kelembagaan Deputi Bidang Kelembagaan dan Sumber Daya Aparatur LAN RI, Kajian Desain Kelembagaan Pemerintah Pusat (Arsitektur Kelembagaan Tahun 20142019), Jakarta, LAN RI, 2013, hlm., 73.

36 Id, hlm., 76.

37 Arfan Faiz Muhlizi, Penataan Regulasi dalam Mendukung Pembangunan Ekonomi Nasional, Jurnal RechtsVinding, Vol. 6, No. 3, Desember 2017, hlm., 352.

38 World Economic Forum, 2019, The Global Competitiveness Report 2019, hlm., 286, http://www3.weforum.org/docs/WEF_TheGlobalCompetitivenessReport2019.pdf, diunduh 1 Juni 2020.

39 Diani Sadiawati et al., Supra no. 24, hlm., 84. 
4,5.40 Nyatanya pemerintah telah gagal dalam memenuhi target yang dicanangkan. Oleh karena itu, pembentukan lembaga tunggal regulasi ini diyakini menjadi jawaban untuk mengentaskan permasalahan tersebut.

Keempat, perlunya memperkuat upaya executive preview untuk mengatasi peraturan daerah (Perda) yang menyebabkan kondisi anti-growth dan high-cost economy. Sebelumnya, pemerintah melalui Gubernur dan Menteri Dalam Negeri pernah membatalkan $3.143^{41}$ Perda bermasalah pada Juni 2016. Pembatalan ini dilatarbelakangi oleh beberapa alasan, yaitu:42 (i) menghambat iklim investasi dan kemudahan berusaha; (ii) bertentangan dengan peraturan yang lebih tinggi dan kepentingan umum; (iii) menegasikan Undang-Undang Nomor 23 Tahun 2014 Tentang Pemerintahan Daerah dan Putusan Mahkamah Konstitusi, seperti persoalan sumber daya air, menara telekomunikasi, Badan Usaha Milik Daerah, dan pengalihan urusan; dan (iv) memuat materi yang dirasa tidak perlu karena berkaitan dengan norma awam yang berlaku di masyarakat.

Dalam perkembangannya, kewenangan pembatalan Perda oleh pemerintah dinyatakan inkonstitusional oleh Mahkamah Konstitusi lewat Putusan Nomor 137/PUU-XIII/2015 dan Nomor 56/PUU-XIV/2016. Oleh karenanya perlu strategi baru untuk menindaklanjuti putusan tersebut, yakni melalui penguatan instansi vertikal dalam penyusunan rancangan Perda. ${ }^{43}$ Mengingat, masih banyak kalangan yang menilai pembentukan Perda hanya sekadar project oriented. ${ }^{44}$ Penyusunan Perda kadang kala muncul secara dadakan di akhir tahun dan tidak sedikit yang

$40 \quad$ Id, hlm., 36.

41 Jumlah yang sebenarnya adalah 3.142 Perda, karena terdapat duplikasi penyebutan pada daftar Perda yang dibatalkan, yaitu Perda Kabupaten Asahan Nomor 8 Tahun 2009 tentang Pengelolaan Barang Milik Daerah yang ditulis sebanyak dua kali pada nomor 72 dan 73.

42 Berdasarkan pemaparan oleh Kurniasih, Direktur Produk Hukum Daerah, Direktorat Jenderal Otonomi Daerah, Kementerian Dalam Negeri. Lihat dalam Leo Agustino, Pembatalan 3.143 Peraturan Daerah: Satu Analisis Singkat, CosmoGov: Jurnal Ilmu Pemerintahan, Vol. 3, No. 1, April 2017, hlm., 16.

43 Bayu Dwi Anggono, Lembaga Khusus di Bidang Pembentukan Peraturan Perundangundangan: Urgensi Adopsi dan Fungsinya Dalam Meningkatkan Kualitas Peraturan Perundangundangan di Indonesia, Jurnal LEGISLASI INDONESIA, Vol. 17, No. 2, Juni 2020, hlm., 139.

44 Charles Simabura, Penataan Produk Hukum Daerah dalam Kerangka Otonomi Daerah, dalam Prosiding Forum Akademik Kebijakan Reformasi Regulasi 2019: Menggagas Arah Kebijakan Reformasi Regulasi di Indonesia, Jakarta: Yayasan Studi Hukum dan Kebijakan Indonesia, 2019, hlm., 144 . 
isinya merupakan copy paste dari Perda daerah lain. ${ }^{45}$ Instansi vertikal yang dimaksud sudah barang tentu adalah kementerian atau lembaga yang menyelenggarakan urusan pemerintahan di bidang pembentukan peraturan perundang-undangan.

Kelima, best practice di negara lain yang menempatkan otoritas pembentukan regulasi pada satu badan/lembaga telah menunjukkan hasil yang memuaskan. Bahkan membantu pemerintah dalam menghasilkan produk hukum yang koheren dan konsisten. ${ }^{46}$ Ini pula yang menjadi alasan bagi OECD untuk merekomendasikan pembentukan lembaga independen yang secara aktif mengawasi seluruh kebijakan pengaturan dan menumbuhkan regulasi yang berkualitas. ${ }^{47}$ Selain itu, rekomendasi ini juga didasarkan pada pertimbangan berikut:

"There is no institution that has formal responsibility for providing a wholeof-government perspective on the implementation of regulatory policy. Rather, a number of public institutions exist to provide with seemingly overlapping responsibilities over regulatory decision making - including the development of tools to support regulatory management and the formal review of regulatory proposals." 48

Salah satu lembaga serupa yang dapat menjadi referensi adalah Regulatory Reform Committee (RRC) milik Korea Selatan. Komite ini berperan dalam perumusan regulasi, termasuk proses peninjauan, penilaian dampak regulasi, dan pengundangan. Secara prinsipil, RRC merupakan badan resmi pemerintah yang bertanggung jawab secara langsung kepada Presiden. ${ }^{49}$ RRC diketuai secara bersama-sama oleh Perdana Menteri dan perwakilan warga sipil.50 Selain itu, keanggotaan RRC terdiri dari 15-20 orang yang berasal dari warga sipil dan para menteri. ${ }^{51}$ Masa tugasnya adalah 2 (dua) tahun dan sesudahnya dapat dipilih

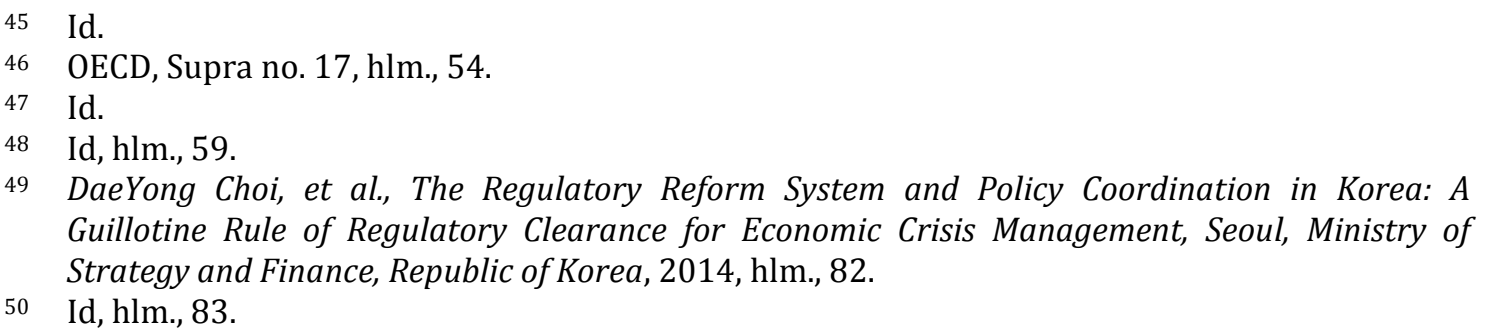


kembali untuk sekali masa tugas. ${ }^{52}$ Adapun struktur kelembagaan RRC dapat dilihat sebagai berikut:

\section{Gambar 1: Regulatory Reform Committee dan Bidang Tugasnya}

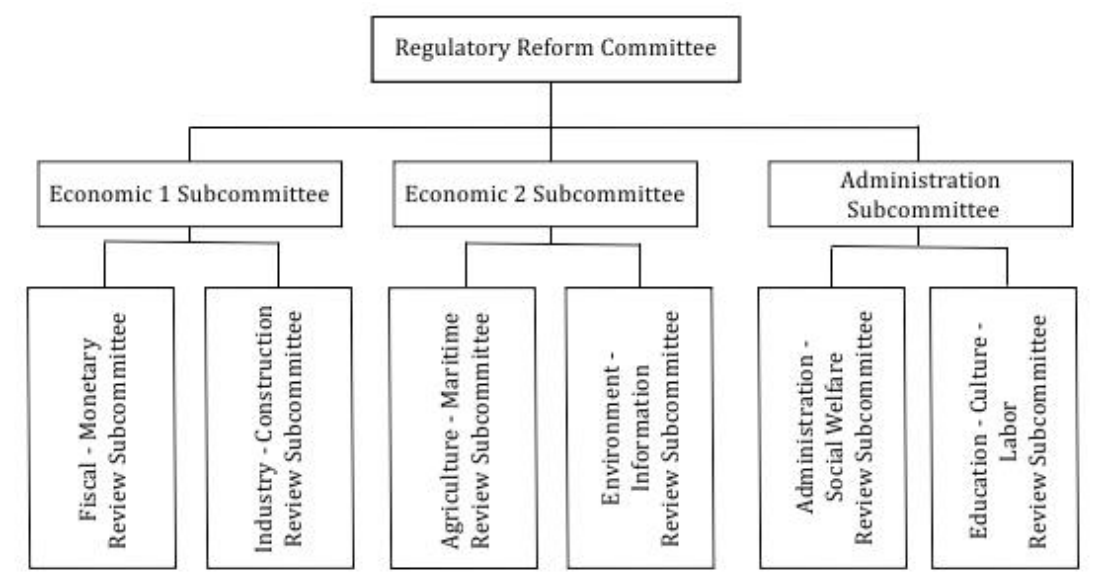

Sumber: DaeYong Choi, et. al., 2014. ${ }^{53}$

Fakta menunjukkan, keberadaan RRC telah berhasil memberikan dampak yang sangat positif. Ha Byung Ki, et al., melaporkan bahwa kinerja RRC berhasil mengefisiensi anggaran negara hingga 590 triliun won pada kurun waktu 19992003.54 Nilai proyeksi untuk investasi asing langsung juga mencapai 36,5 trilun dolar Amerika. ${ }^{55}$ Keberhasilan RRC juga tampak pada indikator kualitas regulasi yang meningkat sebesar 0,54 (skala $-2,5$ sampai 2,5) pasca empat tahun dibentuk. $^{56}$ Bahkan kurun waktu 2014-2018, nilainya konsisten di atas angka 1,0.57 Oleh karenanya Gill dan Ponciano menempatkan Korea Selatan sebagai salah satu negara di Asia dengan sistem manajemen regulasi terbaik..$^{58}$

52 Id, hlm., 83.

53 Id, hlm., 85.

54 Ha Byung Ki, et al., The Economic Effects of Korea's Regulatory Reform, Seoul, Korea Institute for Industrial Economics and Trade, 1999, hlm., 22.

55 Id.

56 The World Bank, South Korea: Regulatory Quality, https://www.theglobaleconomy.com/SouthKorea/wb_regulatory_quality, diakses 7 Desember 2020.

57 Id.

58 Derek Gill and Ponciano Jr. Intal, The Development of Regulatory Management Systems in East Asia: Country Studies, New Zealand, Economic Research Institute for ASEAN and East Asia, 2016, hlm., ix. 


\section{Konstruksi Lembaga Tunggal Pengelola Regulasi di Indonesia}

\section{Tipe Kelembagaan}

Politik hukum Pasal 99A UU PPP telah mengamanatkan untuk membentuk lembaga tunggal regulasi. Hanya saja, pasal ini belum merinci secara jelas bagaimana bentuk dari lembaga tersebut. Frasa yang dimuat sekadar menyebutkan "kementerian atau lembaga yang menyelenggarakan urusan pemerintahan di bidang pembentukan peraturan perundang-undangan." Secara tekstual, frasa tersebut memberikan dua alternatif wujud kelembagaan, yakni dapat berupa kementerian atau lembaga.

Berkaca pada praktik di Indonesia, kita mengenal beberapa tipe kelembagaan pemerintah, di antaranya kementerian negara, LPNK, LNS, dan Sekretariat Kabinet. ${ }^{59}$ Pertama, kementerian negara yang merupakan perangkat pemerintah yang membidangi urusan tertentu dalam pemerintahan. ${ }^{60}$ Secara yuridis, eksistensinya didasarkan pada Pasal 17 Undang-Undang Dasar Negara Republik Indonesia Tahun 1945 (UUD 1945), yang kemudian diatur lebih lanjut di dalam Undang-Undang Nomor 39 Tahun 2008 Tentang Kementerian Negara (UU Kementerian). Kedua, LPNK yang dibentuk sebagai special agency untuk melaksanakan tugas spesifik tertentu yang tidak ditangani oleh kementerian. ${ }^{61}$ Lembaga ini berkedudukan di bawah Presiden dan bertanggung jawab kepadanya melalui menteri yang mengkoordinasikan.62 Berdasarkan tujuan dari pembentukannya, LPNK terbagi menjadi 4 (empat) kelompok berikut:

a. LPNK pendukung yang menyelenggarakan fungsi dukungan terhadap kementerian atau lembaga di bidang manajemen pemerintahan, seperti: Lembaga Administrasi Negara, Badan Perencanaan Pembangunan Nasional, dan lain-lain.

b. LPNK pendukung yang menyelenggarakan fungsi dukungan terhadap kementerian atau lembaga di bidang substansi pemerintah tertentu,

59 Pusat Kajian Kinerja Kelembagaan Deputi Bidang Kelembagaan dan Sumber Daya Aparatur LAN RI, Supra no. 32, hlm., 60.

60 Lihat Pasal 1 angka 1 Undang-Undang Nomor 39 Tahun 2008 Tentang Kementerian Negara, Lembaran Negara RI Tahun 2008 Nomor 166, Tambahan Lembaran Negara RI Nomor 4916.

61 Pusat Kajian Kinerja Kelembagaan Deputi Bidang Kelembagaan dan Sumber Daya Aparatur LAN RI. Op.Cit, hlm., 71.

62 Lihat Pasal 27 ayat (2) Undang-Undang Nomor 39 Tahun 2008 Tentang Kementerian Negara, Lembaran Negara RI Tahun 2008 Nomor 166, Tambahan Lembaran Negara RI Nomor 4916. 
seperti: Badan Pusat Statistik, Badan Nasional Penanggulangan Bencana, dan lain-lain.

c. LPNK yang masih menyelenggarakan fungsi pelayanan dan regulasi publik, seperti: Badan Pertanahan Nasional, Badan Pengawasan Obat dan Makanan, Badan Koordinasi Penanaman Modal, dan Badan Nasional Penempatan dan Perlindungan Tenaga Kerja Indonesia.

d. LPNK yang berfokus pada tugas dan fungsi pengkajian dan penelitian, seperti: Lembaga Ilmu Pengetahuan Indonesia, Lembaga Penerbangan dan Antariksa Nasional, dan lain-lain. ${ }^{63}$

Ketiga, LNS adalah lembaga quasi dari pemerintah dan masyarakat.64 Umumnya LNS bersifat independen dalam menjalankan tugas dan fungsinya, serta berada di luar kementerian, LPNK, atau lembaga pemerintah lainnya. ${ }^{65}$ Seperti didefinisikan oleh Hamdan Zoelva66 bahwa "LNS adalah institusi yang dibentuk karena urgensi terhadap tugas khusus tertentu yang tidak dapat diwadahi dalam kelembagaan pemerintah (konvensional) dengan keunikan tertentu dan memiliki karakteristik tugas yang urgen, unik, dan terintegrasi serta efektif." Keempat, Sekretariat Kabinet yang merupakan organisasi pemerintah pusat dengan kedudukan setingkat kementerian. Secara yuridis, Sekretariat Kabinet ditempatkan di bawah dan bertanggung jawab kepada Presiden.67 Dalam operasionalisasi, Sekretariat Kabinet dipimpin oleh seorang Sekretaris Kabinet. 68 Adapun tugasnya memberikan dukungan manajemen kabinet kepada Presiden dan Wakil Presiden dalam penyelenggaraan pemerintahan. 69

Jika tipe kementerian yang dipilih, maka Presiden harus mempertimbangkan keberadaan UU Kementerian. UU ini membagi urusan tertentu yang dijalankan oleh kementerian menjadi 3 (tiga) kelompok, yaitu: ${ }^{70}$ (i)

\footnotetext{
Id, hlm., 74.

Id, hlm., 75 .

Id, hlm., 77.

66 Hamdan Zoelva, Tinjauan Konstitusional Penataan Lembaga Non-Struktural di Indonesia, Negarawan: Jurnal Sekretariat Negara RI, No. 18, November 2010, hlm., 68.

67 Lihat Pasal 1 angka 1 Peraturan Presiden Nomor 55 Tahun 2020 Tentang Sekretariat Kabinet, Lembaran Negara RI Tahun 2020 Nomor 95.

68 Lihat Pasal 1 angka 2 Peraturan Presiden Nomor 55 Tahun 2020 Tentang Sekretariat Kabinet, Lembaran Negara RI Tahun 2020 Nomor 95.

69 Pasal 2 Peraturan Presiden Nomor 55 Tahun 2020 Tentang Sekretariat Kabinet, Lembaran Negara RI Tahun 2020 Nomor 95.

70 Pasal 4 ayat (2) Undang-Undang Nomor 39 Tahun 2008 Tentang Kementerian Negara, Lembaran Negara RI Tahun 2008 Nomor 166, Tambahan Lembaran Negara RI Nomor 4916.
} 
urusan yang nomenklatur kementeriannya secara tegas disebutkan dalam UUD 1945; (ii) urusan pemerintahan yang ruang lingkupnya disebutkan dalam UUD 1945; dan (iii) urusan pemerintahan dalam rangka penajaman, koordinasi, dan sinkronisasi program pemerintah. Sejauh ini, UU Kementerian belum secara eksplisit menyebutkan urusan pembentukan peraturan perundang-undangan masuk ke dalam kelompok mana. Oce Madril menilai, tugas tersebut harusnya masuk ruang lingkup kelompok kedua karena menjadi bagian dari urusan pemerintahan di bidang hukum. ${ }^{71}$ Akan tetapi, politik hukum UU PPP menjadikan urusan pembentukan peraturan perundang-undangan sebagai urusan tersendiri dan dipisahkan dari urusan Kementerian Hukum. ${ }^{72}$ Di samping itu, Jimmy Z. Usfunan mengatakan, pilihan tipe kementerian akan lebih sulit diwujudkan karena adanya limitasi jumlah kementerian dalam Pasal 15 ayat (2) UU Kementerian. ${ }^{73}$

Apabila wujudnya kelembagaan, maka ada dua pilihan tipe yakni LPNK atau LNS. Secara praktik-yuridis, pembentukan LPNK maupun LNS akan lebih mudah ketimbang kementerian. Namun, kedudukan lembaga-lembaga ini tidak sekuat kementerian. ${ }^{74}$ Keberadaan LPNK yang dikoordinasikan oleh menteri, menunjukkan lembaga ini tidak secara langsung berada di bawah kendali Presiden. Hal ini tampak juga dari tujuan pembentukan LPNK, yang lebih diarahkan pada tugas dukungan terhadap kementerian.

Adapun LNS sifatnya sebagai lembaga independen. Secara garis besar, ada dua tujuan yang hendak dicapai dari independensinya sebuah lembaga, yaitu:75 (i) lepas dari pengaruh kepentingan politik manapun dan intervensi dari tiga cabang

71 Oce Madril, Pembentukan Lembaga Regulasi Nasional Sebagai Upaya Reformasi Regulasi, dalam Prosiding Forum Akademik Kebijakan Reformasi Regulasi 2019: Menggagas Arah Kebijakan Reformasi Regulasi di Indonesia, Jakarta, Yayasan Studi Hukum dan Kebijakan Indonesia, 2019, hlm., 467.

72 Id.

73 Jimmy Z. Usfunan, Lembaga Pembentuk Perundang-undangan di Luar Kementerian, Efektifkah?, dalam Prosiding Forum Akademik Kebijakan Reformasi Regulasi 2019: Menggagas Arah Kebijakan Reformasi Regulasi di Indonesia, Jakarta, Yayasan Studi Hukum dan Kebijakan Indonesia, 2019, hlm., 296.

74 Oce Madril, Supra no 71

75 Hendra Nurtjahjo, Makalah berjudul "Lembaga, Badan, dan Komisi Negara Independen (State Auxiliary Agencies) di Indonesia: Tinjauan Hukum Tata Negara," disampaikan dalam Diskusi terbatas tentang Kelembagaan Independen di Indonesia yang diselenggarakan oleh Lembaga Administrasi Negara RI, Jakarta, 2005, hlm., 283. 
kekuasaan; (ii) bebas dari fungsi-fungsi titipan lembaga manapun yang mengacaukan tugas dan fungsinya sebagai lembaga penunjang negara. Dengan desain semacam ini, tentunya tidak sesuai dengan arah politik hukum UU PPP, yang mengamanatkan lembaga tunggal regulasi untuk menangani pembentukan regulasi di lingkungan eksekutif.

Dalam menentukan desain lembaga tunggal pengelola regulasi, Oce Madril memberikan 4 (empat) kriteria utama, yaitu:76 (i) desain kelembagaan yang kuat dan efektif; (ii) harus dibentuk dan berada langsung di bawah Presiden; (iii) kepala lembaganya setingkat dengan menteri yang diangkat langsung oleh Presiden; dan (iv) menjadi bagian dari lembaga-lembaga yang berada di lingkungan istana. Berpijak pada kriteria tersebut, kemudian ia mengusulkan untuk menggunakan tipe Sekretariat Kabinet. Menurutnya, dengan tipe ini akan terlihat jelas bahwa lembaga tunggal pengelola regulasi memiliki kedudukan dan peran yang strategis. ${ }^{77}$

Hampir senada dengan kriteria di atas, Cesar dan Jacobzone dalam penelitiannya mengatakan bahwa 20 dari 22 negara meletakkan otoritas tunggal pengelola regulasi di dalam kantor kepresidenan atau perdana menteri. ${ }^{78}$ Sebagai contoh RRC di Korea Selatan yang sering disebut-sebut sebagai milik Blue House (Istana Kepresidenan Korea Selatan). Faktanya dengan model penempatan yang demikian menjadi salah satu elemen kunci kesuksesan Korea Selatan dalam penerapan lembaga tunggal pengelola regulasi.

Dengan mengambil dua pendapat di atas sebagai titik tolak, maka penulis lebih sepakat dengan tipe terakhir. Ditinjau dari segi utilitas, tipe Sekretariat Kabinet sejatinya akan memperkuat dukungan politik dari para decision maker tertinggi. Dengan kata lain, semakin dekat lembaga pengelola regulasi dengan pusat pemerintahan, maka semakin dekat lembaga itu dengan inti dari proses pengambilan keputusan pemerintah. Hal ini akan semakin memberikan jaminan

Oce Madril, Supra no 71

Id.

78 Cesar Cordova-Novion dan Stephane Jacobzone, Strengthening the Institutional Setting for Regulatory Reform: The Experience from OECD Countries, OECD Working Papers on Public Governance, OECD Publishing, No. 19, 2011, hlm., 39. 
dan kepastian, bahwa hasil kinerjanya diterima atau dimasukkan ke dalam proses pengambilan keputusan itu. Seperti yang dikatakan oleh Wiener: ${ }^{79}$

"Locating the Regulatory Oversight Body (ROB) in a politically accountable part of the Centre-of-government, such as the presidency or prime minister's office, can help ensure that it is understood to be accountable to the electorate and exercising good judgment. This can be appealing to the broader public and help to counter the technocratic bias, and also allay the fear linked to the role of regulated industry or other interest groups. ... The ultimate protection for a ROB may be its ability to show that it exercises oversight effectively and even-handedly, delivering high quality analysis that has improved overall regulatory outcomes. Still, the ROB will need the backing of a policy reform leader, possibly at the Centre-of-government, and perceived legitimacy among regulated parties, regulatory beneficiaries, and the public."

Oleh karenanya, penulis menawarkan untuk nomenklatur lembaga ini nantinya adalah "Sekretariat Perundang-undangan." Secara terminologi, nomina "perundang-undangan" dalam Juridisch Woordenboek memiliki 2 (dua) pengertian: 80 Pertama, proses pembentukan atau proses membentuk peraturan negara, baik di tingkat pusat maupun daerah. Kedua, segala peraturan negara, yang merupakan hasil pembentukan peraturan, baik di tingkat pusat maupun daerah. Berdasarkan pengertian ini, maka nomenklatur tersebut dapat dimaknai sebagai lembaga yang menangani proses pembentukan peraturan perundangundangan sebagaimana dimaksud dalam UU PPP.

\section{Desain Kewenangan}

Secara yuridis, UU PPP telah menentukan kewenangan yang dimiliki oleh kementerian atau lembaga pembentuk regulasi yang diejawantahkan ke dalam fungsi-fungsi pembentukan regulasi. Terkait fungsi-fungsi yang dijalankan, dapat dibaca pada tabel di bawah ini:

79 Jonathan B. Wiener, Makalah berjudul "Issues in the Comparison of Regulatory Oversight Bodies" disampaikan pada OECD Working Party in Paris, France, 21-22 Oktober 2008, hlm., 7-8.

80 Maria Farida Indrati Soeprapto, Ilmu Perundang-Undangan 1: Jenis, Fungsi, dan Materi Muatan, Yogyakarta, Kanisius, 2007, hlm., 10. 
Tabel 2: Kewenangan Lembaga Pengelola Regulasi Menurut UU PPP

\begin{tabular}{|c|c|c|}
\hline No. & Kewenangan & Pasal \\
\hline 1 & Penyusunan Prolegnas di lingkungan Pemerintah. & Pasal 21 ayat (4) \\
\hline 2 & $\begin{array}{l}\text { Memberikan persetujuan bersama-sama alat kelengkapan } \\
\text { DPR yang khusus menangani bidang legislasi atas keadaan } \\
\text { tertentu yang memastikan adanya urgensi nasional dalam hal } \\
\text { Rancangan Undang-Undang yang diajukan di luar Prolegnas. }\end{array}$ & Pasal 23 ayat $(2 \mathrm{~b})$ \\
\hline 3 & Perencanaan penyusunan Peraturan Pemerintah. & Pasal 26 ayat (1) \\
\hline 4 & $\begin{array}{l}\text { Pengharmonisasian, pembulatan, dan pemantapan konsepsi } \\
\text { Rancangan Undang-Undang yang berasal dari Presiden. }\end{array}$ & Pasal 47 ayat (3) \\
\hline 5 & $\begin{array}{l}\text { Berkoordinasi dengan menteri lain yang ditugasi mewakili } \\
\text { Presiden atas persiapan pembahasan Rancangan Undang- } \\
\text { Undang bersama DPR dalam jangka waktu paling lama } 60 \\
\text { (enam puluh) hari terhitung sejak surat pimpinan DPR } \\
\text { diterima. }\end{array}$ & Pasal 49 ayat (3) \\
\hline 6 & $\begin{array}{l}\text { Pengharmonisasian, pembulatan, dan pemantapan konsepsi } \\
\text { Rancangan Peraturan Pemerintah. }\end{array}$ & Pasal 54 ayat (2) \\
\hline 7 & $\begin{array}{l}\text { Pengharmonisasian, pembulatan, dan pemantapan konsepsi } \\
\text { Rancangan Peraturan Presiden. }\end{array}$ & Pasal 55 ayat (2) \\
\hline 8 & $\begin{array}{l}\text { Pengharmonisasian, pembulatan, dan pemantapan konsepsi } \\
\text { Rancangan Peraturan Daerah Provinsi yang berasal dari } \\
\text { Gubernur. }\end{array}$ & Pasal 58 ayat (2) \\
\hline 9 & $\begin{array}{l}\text { Pengundangan Peraturan Perundang-undangan dalam } \\
\text { Lembaran Negara Republik Indonesia atau Berita Negara } \\
\text { Republik Indonesia sebagaimana dimaksud dalam Pasal } 82 \\
\text { dan Pasal } 83 .\end{array}$ & Pasal 85 \\
\hline 10 & $\begin{array}{l}\text { Menerjemahkan Peraturan Perundang-undangan } \\
\text { diterjemahkan ke dalam bahasa asing. }\end{array}$ & Pasal 91 \\
\hline
\end{tabular}

Sumber: Undang-Undang Nomor 15 Tahun 2019.

Jika diamati, sebenarnya kewenangan di atas merupakan kewenangan yang sebelumnya telah ada. ${ }^{81}$ Kewenangan itu hanya bersifat pengalihan atas kewenangan dari instansi lama. Hal ini tampak pada perubahan pasal yang sebatas mengganti frasa "menteri/lembaga yang berwenang dalam pembentukan perundang-undangan" menjadi "menteri atau lembaga yang bertanggung jawab di bidang pembentukan peraturan perundang-undangan."82

81 Bandingkan dengan Bayu Dwi Anggono, Reformasi Regulasi untuk Penguatan Substansi dan Prosedur Pembentukan Peraturan Perundang-undangan (Telaah Perubahan Undang-Undang Nomor 12 Tahun 2011), dalam Prosiding Forum Akademik Kebijakan Reformasi Regulasi 2019: Menggagas Arah Kebijakan Reformasi Regulasi di Indonesia, Jakarta, Yayasan Studi Hukum dan Kebijakan Indonesia, 2019, hlm., 351.

82 Khairul Fahmi, Otonomi Daerah dalam Ancaman Resentralisasi Pembentukan Peraturan Perundang-undangan, dalam Prosiding Forum Akademik Kebijakan Reformasi Regulasi 2019: Menggagas Arah Kebijakan Reformasi Regulasi di Indonesia, Jakarta, Yayasan Studi Hukum dan Kebijakan Indonesia, 2019, hlm., 155. 
Selain itu, kewenangan tersebut juga masih cukup terbatas. Misalnya dalam hal perencanaan yang hanya menyangkut rancangan UU inisiatif Presiden, rancangan PP, dan rancangan Perpres. Sementara itu, rancangan peraturan menteri dan rancangan peraturan LPNK tidak disebutkan sebagai kewenangan lembaga ini. Padahal di awal telah diuraikan, peraturan menteri menjadi sumber masalah regulasi terbesar di Indonesia.

Dalam hal pemantauan dan peninjauan juga tidak disebutkan secara ekplisit menjadi kewenangan yang dikoordinasikan oleh lembaga tunggal ini. Jika nantinya mewakili frasa "pemerintah" seperti diatur dalam Pasal 95A ayat (2) UU PPP83, itu pun terbatas pada UU. ${ }^{84}$ Dengan kata lain, lembaga tunggal tersebut tidak mengoordinasikan pemantauan dan peninjauan terhadap regulasi di bawah UU yang notabene-nya menjadi ranah eksekutif. Penggunaan frasa "koordinasi"85 juga tidak memberikan jaminan bahwa lembaga ini didesain untuk mempunyai daya imperatif yang berimplikasi secara politis dan yuridis. Artinya, belum bisa dipastikan apakah setiap hasil tinjauannya bersifat wajib untuk ditindaklanjuti oleh pemrakarsa atau sekadar menjadi pertimbangan. Bayu Dwi Anggono menambahkan, adanya kata "koordinasi" mengindikasikan kewenangan lembaga baru ini tidak ada bendanya dengan sebelumnya. ${ }^{86}$

Sebagai tolak ukur, fungsi RRC milik Korea Selatan dalam pengelolaan regulasi mencakup tugas-tugas vital dan strategis. Sebagaimana diuraikan dalam White Paper on Regulatory Reform, fungsi yang dijalankan oleh RRC adalah sebagai berikut: (i) menentukan arah kebijakan reformasi regulasi serta arah penelitian dan pengembangan sistem regulasi; (ii) meninjau rancangan regulasi untuk diperkuat; (iii) mengevaluasi dan meng-update regulasi yang ada; (iv) merencanakan, menyusun, dan mengimplemantasikan program peninjauan dan

83 Pasal ini menyebutkan "Pemantauan dan Peninjauan terhadap Undang-Undang sebagaimana dimaksud pada ayat (1) dilaksanakan oleh DPR, DPD, dan Pemerintah."

84 Lihat Pasal 95A ayat (1) Undang-Undang Nomor 15 Tahun 2019 Tentang Perubahan Atas Undang-Undang Nomor 12 Tahun 2011 Tentang Pembentukan Peraturan Perundangundangan, Lembaran Negara RI Tahun 2019 Nomor 183, Tambahan Lembaran Negara RI Nomor 6398.

85 Hampir di setiap pasal UU PPP yang mengatur kewenangan lembaga tungga ini memuat frasa "dikoordinasikan".

86 Bayu Dwi Anggono, Supra no. 40, hlm., 142. 
reformasi regulasi yang komprehensif; (v) meregister dan mempublikasikan regulasi; (vi) memeriksa dan mengevaluasi status dan progres regulasi yang ada di setiap lembaga yang ada di lingkungan eksekutif secara aktual; dan (vii) menerima pendapat dan saran tentang bagaimana cara mereformasi atau merevisi regulasi. ${ }^{87}$

Dalam hal peninjauan usulan regulasi baru oleh RRC, rangkaian proses yang terjadi dapat diuraikan sebagai berikut: 88

a. Kementerian yang mengusulkan regulasi harus menyusun penilaian dampak regulasi dan penyiapan dokumen resmi yang secara eksplisit memuat biaya dan manfaat regulasi yang diusulkan, serta metode alternatif yang digunakan untuk mencapai tujuan pengaturan.

b. Kementerian tersebut kemudian melakukan self-review terhadap rancangan dan dokumen penilaian yang telah disusun.

c. Selanjutnya kementerian pemrakarsa mengajukan rancangan beserta dokumen-dokumen pendukung yang telah disusun tadi kepada RRC.

d. Selama proses peninjauan di RRC, pertama-tama proposal yang diserahkan oleh kementerian tadi diperiksa oleh sub-komite bedasarkan lingkup dan fungsinya. Diskusi dan koordinasi lebih banyak terjadi selama proses ini.

e. Setelah dari sub-komite, RRC akan melakukan peninjauan penuh secara komprehensif dengan mendasarkan pada diskusi dan hasil keputusan dari sub-komite.

f. Peninjauan terjadi dua kali (rapat sub-komite dan rapat RRC sendiri) dalam hal regulasi yang akan dibentuk atau diubah dianggap signifikan, yakni mempunyai dampak finansial lebih dari 10 juta won per tahun dan mempengaruhi lebih dari satu juta orang. Sedangkan untuk regulasi yang tidak dianggap signifikan, cukup diselesaikan dalam rapat sub-komite.

Sedangkan terhadap regulasi yang telah berlaku, proses reviu terjadi dalam beberapa tahap. Pertama, kementerian yang membuatnya melakukan self-review. Kedua, kementerian bekerja sama dengan lembaga terkait lainnya melakukan working group review. Ketiga, peninjauan oleh sub-komite RRC. Keempat, peninjauan akhir pada rapat penuh RRC. ${ }^{89}$ Selain melakukan peninjauan tersebut, RRC juga melakukan pemeriksaan dan pemeliharaan daftar regulasi. Bahkan

87 Regulatory Reform Committee, White Paper on Regulatory Reform, Seoul, RRC, 2002, hlm., 32.

88 Id, hlm., 98.

89 Kim Song June dan Choi Dae Yong, Regulatory Coherence: The Case of the Republic of Korea, Discussion Paper of Economic Research Institute for ASEAN and East Asia and New Zealand Institute of Economic Research, No. 2016-15, 2016, hlm., 18. 
secara teknis, suatu regulasi hanya sah dan dapat diimplementasikan apabila telah dimasukkan dalam daftar registrasi RRC. ${ }^{90}$

OECD dalam reviunya juga turut memberikan rekomendasi bagaimana kewenangan yang seharusnya dimiliki oleh lembaga tunggal pengelola regulasi di Indonesia, di antaranya:

a. Responsibility to formulate regulatory policy goals, strategies and benefits, including developing and implementing a communications strategy to secure ongoing support for regulatory quality;

b. Examining the potential for regulation to be more effective including promoting the consideration of regulatory measures in areas of policy where regulation is likely to be necessary;

c. Co-ordinating ex post evaluation for policy revision and for refinement of ex ante methods;

d. Quality control through the review of the quality of impact assessments and returning proposed rules for which impact assessments are inadequate;

e. Providing training and guidance on impact assessment and strategies for improving regulatory performance; and

f. Responsibility for monitoring and periodic reporting on regulatory management system performance. ${ }^{91}$

Mengelaborasikan dengan pandangan-pandangan di atas maka sudah semestinya kewenangan lembaga tunggal ini diperkuat, yang meliputi: (i) kewenangan untuk melakukan perencanaan dan penyusunan rancangan UU inisiatif Presiden, PP, Perpres, peraturan menteri, peraturan LPNK, bahkan jika perlu sampai peraturan LNS; (ii) melakukan harmonisasi dan sinkronisasi rancangan-rancangan tersebut ditambah dengan rancangan Perda; (iii) melakukan evaluasi dan pemantauan secara komprehensif dan sifatnya imperatif atas UU, PP, Perpres, peraturan menteri, peraturan LPNK, peraturan LNS, dan Perda; (iv) menjadi pusat dokumentasi dan jaringan informasi seluruh regulasi; (v) kewenangan litigasi-non litigasi, pembinaan, dan pengembangan SDM dalam bidang pembentukan regulasi; (vi) mengukur biaya dan manfaat regulasi yang diusulkan atau telah diterbitkan; dan (vii) memberikan limitasi waktu, khususnya dalam proses pemantauan dan peninjauan.

\footnotetext{
90 DaeYong Choi, et al., Supra no. 49, hlm., 92.

91 OECD, Supra no. 46, hlm., 52.
} 


\section{Struktur Kelembagaan}

Mendasarkan pada luasnya dimensi yang diusulkan, maka struktur kelembagaan Sekretariat Perundang-undangan diharapkan mempunyai kapasitas dan kapabilitas dalam menjawab tantangan tersebut. Terhadap hal ini penting rasanya belajar dari strategi Korea Selatan yang mendapat dukungan langsung dari Presiden melalui Perdana Menteri. Oleh karena itu, gagasan yang diusulkan untuk struktur kelembagaan adalah sebagai berikut:

\section{Gambar 2: Struktur Kelembagaan Sekretariat Perundang-undangan}

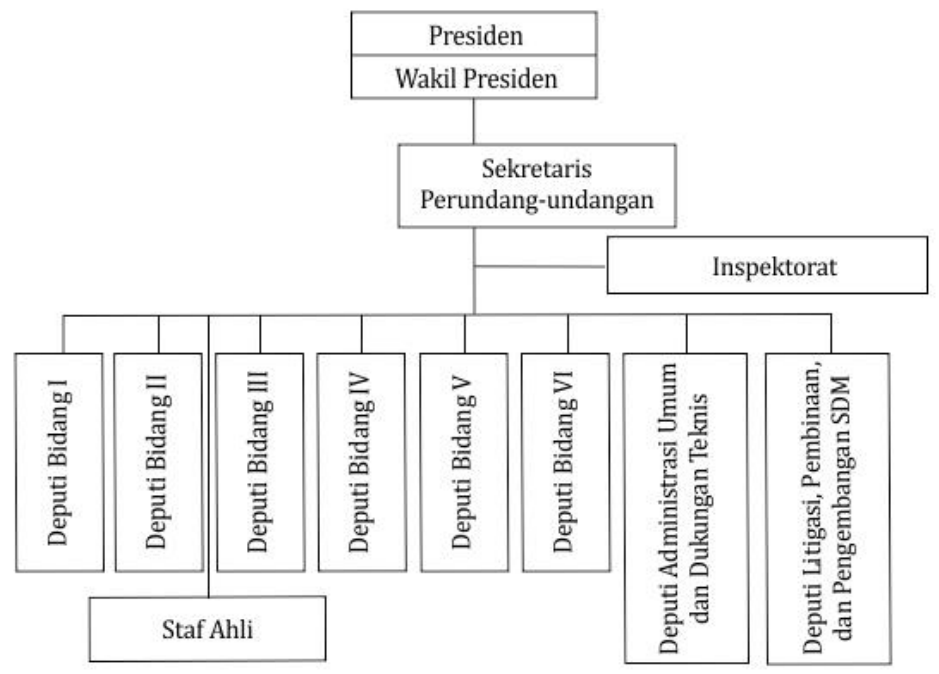

Sumber: Rilo Pambudi. S, 2020.92

Terhadap susunan kelembagaan di atas dapat diuraikan sebagai berikut:

a. Sekretaris Perundang-undangan atau penyebutan lain yang sekiranya tepat adalah pimpinan sekretariat yang diangkat dan diberhentikan oleh Presiden. Kedudukannya setara dengan menteri. Tugasnya memimpin dan bertanggung jawab atas pelaksanaan tugas dan fungsi dari Sekretariat Perundangundangan.

b. Inspektorat dipimpin oleh Inspektur yang berada di bawah dan bertanggung jawab kepada Sekretaris Perundang-undangan. Tugasnya melakukan pengawasan internal.

92 Rilo Pambudi. S, Konstruksi Lembaga Tunggal Pengelola Regulasi di Indonesia, Skripsi, Universitas Maritim Raja Ali Haji, 2020, hlm., 182. 
c. Deputi Bidang I-VI berada di bawah dan bertanggung jawab kepada Sekretaris Perundang-undangan. Tugasnya menangani pembentukan, pemantauan, dan evaluasi peraturan perundang-undangan di bidang Politik, Hukum, Pertahanan, dan Keamanan (Deputi Bidang I), Pembangunan Manusia dan Kebudayaan (Deputi Bidang II), Perekonomian (Deputi Bidang III), Kemaritiman, Pambangunan, dan Investasi (Deputi Bidang IV), proses harmonisasi peraturan perundang-undangan di daerah (Deputi Bidang V), dan Deputi Bidang VI khusus menangani tahapan pengundangan dan sebagai pusat dokumentasi dan jaringan informasi perundang-undangan.

d. Deputi Administrasi Umum dan Dukungan Teknis berada di bawah dan bertanggung jawab kepada Sekretaris Perundang-undangan. Tugasnya memberikan dukungan manajemen dan administasi di lingkungan kelembagaan.

e. Deputi Litigasi, Pembinaan, dan Pengembangan SDM berada di bawah dan bertanggung jawab kepada Sekretaris Perundang-undangan. Tugasnya menyelenggarakan proses litigasi, pembinaan, pelatihan, serta pengelolaan dan pengembangan sumber daya manusia di lingkungan kelembagaan.

f. Staf Ahli berada di bawah dan bertanggung jawab kepada Sekretaris Perundang-undangan. Tugasnya memberikan pandangan, saran, dan rekomendasi terkait isu-isu strategis dan aktual kepada Sekretaris Perundangundangan.

Di samping itu, dalam rangka menciptakan efisiensi dan efektivitas pelaksanaan tugas dan fungsi, masing-masing deputi dapat juga membentuk unitunit yang lebih kecil. Pembentukan tersebut tentunya harus memenuhi beberapa pertimbangan, di antaranya pertimbangan efektivitas dan efisiensi; cakupan tugas dan proporsionalitas beban tugas; kesinambungan, keserasian, dan keterpaduan pelaksanaan tugas; serta perkembangan dan tuntutan lingkungan global.

\section{Penutup}

Berdasarkan hasil analisis dan pembahasan yang telah dilakukan, maka dapat ditarik kesimpulan bahwa dasar pemikiran pembentukan lembaga 
pengelola regulasi adalah: Pertama, Undang-Undang Nomor 12 Tahun 2011 Tentang Pembentukan Peraturan Perundang-undangan menempatkan fungsifungsi pembentukan regulasi tersebar di berbagai kementerian/lembaga. Kedua, pembentukan regulasi yang berlangsung saat ini masih mengedepankan pendekatan sektoral ketimbang pendekatan sistem. Ketiga, adanya tumpang tindih, disharmonisasi, dan ketidaksinkronan regulasi yang menyebabkan ketidakpastian hukum dan hilangnya benang merah politik hukum yang telah ditetapkan sebelumnya. Keempat, perlunya memperkuat upaya executive preview untuk mengatasi Perda yang menyebabkan kondisi anti-growth dan high-cost economy. Kelima, best practice di negara lain yang menempatkan otoritas pembentukan regulasi pada satu badan/lembaga telah menunjukkan hasil yang memuaskan.

Kemudian, berpegang pada UU PPP dan best practice di negara lain, maka konstruksi kelembagaan yang dapat diterapkan di Indonesia penulis sajikan sebagai berikut:

a. Pasal 99A UU PPP belum merinci secara jelas bagaimana bentuk dari lembaga tunggal regulasi. Berkaca pada praktik di Indonesia, terdapat beberapa tipe yang dapat diterapkan, yakni kementerian, LPNK, LNS, dan Sekretariat Kabinet. Kendati demikian, penulis lebih sepakat dengan tipe Sekretariat Kabinet. Oleh karenanya nomenklatur yang diusulkan adalah "Sekretariat Perundang-undangan."

b. Secara substantif, desain kewenangan lembaga ini dalam UU PPP merupakan kewenangan yang sebelumnya telah ada. Kewenangan ini bersifat pengalihan dan masih terbatas, sehingga perlu memperkuat kewenangan lembaga tunggal ini, yang meliputi: (i) melakukan perencanaan dan penyusunan rancangan UU inisiatif Presiden, PP, Perpres, peraturan menteri, peraturan LPNK, bahkan jika perlu sampai peraturan LNS; (ii) melakukan harmonisasi dan sinkronisasi rancangan-rancangan tersebut ditambah dengan rancangan Perda; (iii) melakukan evaluasi dan pemantauan secara komprehensif dan sifatnya imperatif atas UU, PP, Perpres, peraturan menteri, peraturan LPNK, peraturan LNS, dan Perda; (iv) menjadi pusat penyebarluasan informasi seluruh regulasi; 
(v) kewenangan litigasi dan pengembangan SDM dalam bidang pembentukan regulasi; (vi) mengukur biaya dan manfaat regulasi yang diusulkan atau telah diterbitkan; dan (vii) memberikan limitasi waktu, khususnya dalam proses pemantauan dan peninjauan.

c. Struktur kelembagaan ditempatkan di bawah dan bertanggung jawab kepada Presiden. Susunan oraganisasinya terdiri dari Sekretaris Perundang-undangan, Inspektorat, Deputi-deputi, dan Staf Ahli. Dalam mencapai efektivitas dan efisiensi dapat pula dibentuk unit-unit tambahan.

\section{Daftar Pustaka}

Buku:

DaeYong Choi, et al., The Regulatory Reform System and Policy Coordination in Korea: A Guillotine Rule of Regulatory Clearance for Economic Crisis Management. Seoul: Ministry of Strategy and Finance, Republic of Korea, 2014.

Derek Gill and Ponciano Jr. Intal, The Development of Regulatory Management Systems in East Asia: Country Studies, New Zealand, Economic Research Institute for ASEAN and East Asia, 2016.

Diani Sadiawati, et al., Strategi Nasional Reformulasi Regulasi, Jakarta, Bappenas, 2015.

Diani Sadiawati, et al., Kajian Reformasi Regulasi di Indonesia: Pokok Permasalahan dan Strategi Penanganannya, Jakarta, Yayasan Studi Hukum dan Kebijakan Indonesia, 2019.

Ha Byung Ki, The Economic Effects of Korea's Regulatory Reform, Seoul, Korea Institute for Industrial Economics and Trade, 1999.

Johnny Ibrahim, Teori dan Metodologi Penelitian Hukum Normatif, Malang, Bayumedia Publishing, 2006.

Maria Farida Indrati Soeprapto, Ilmu Perundang-Undangan 1: Jenis, Fungsi, dan Materi Muatan, Yogyakarta, Kanisius, 2007.

OECD, Reviews of Regulatory Reform Indonesia: Government Capacity to Assure High Quality Regulation, Paris, OECD, 2012.

Oksep Adhayanto, Eksistensi Hak Preogratif Presiden, Tanjungpinang, UMRAH Press, 2015. 
Pusat Kajian Kinerja Kelembagaan Deputi Bidang Kelembagaan dan Sumber Daya Aparatur LAN RI, Kajian Desain Kelembagaan Pemerintah Pusat (Arsitektur Kelembagaan Tahun 2014-2019), Jakarta, LAN RI, 2013.

Regulatory Reform Committee, White Paper on Regulatory Reform, Seoul, RRC, 2002.

\section{Jurnal/Prosiding:}

Arfan Faiz Muhlizi, Penataan Regulasi dalam Mendukung Pembangunan Ekonomi Nasional, Jurnal RechtsVinding, Volume 6, Nomor 3, Desember 2017.

Bayu Dwi Anggono, Lembaga Khusus di Bidang Pembentukan Peraturan Perundang-Undangan: Urgensi Adopsi dan Fungsinya dalam Meningkatkan Kualitas Peraturan Perundang-Undangan di Indonesia, Jurnal LEGISLASI INDONESIA, Volume 17, Nomor 2, Juni 2020.

Bayu Dwi Anggono, Reformasi Regulasi Untuk Penguatan Substansi dan Prosedur Pembentukan Peraturan Perundang-Undangan (Telaah Perubahan Undang-Undang Nomor 12 Tahun 2011), dalam Prosiding Forum Akademik Kebijakan Reformasi Regulasi 2019: Menggagas Arah Kebijakan Reformasi Regulasi di Indonesia, Jakarta, Yayasan Studi Hukum dan Kebijakan Indonesia, 2019.

Cesar Cordova-Novion and Stephane Jacobzone, Strengthening the Institutional Setting for Regulatory Reform: The Experience from OECD Countries, OECD Publishing, Nomor 19, 2011.

Charles Simabura, Penataan Produk Hukum Daerah dalam Kerangka Otonomi Daerah dalam Prosiding Forum Akademik Kebijakan Reformasi Regulasi 2019: Menggagas Arah Kebijakan Reformasi Regulasi di Indonesia, Jakarta, Yayasan Studi Hukum dan Kebijakan Indonesia, 2019.

Hamdan Zoelva, Tinjauan Konstitusional Penataan Lembaga Non-Struktural di Indonesia, Negarawan: Jurnal Sekretariat Negara RI, Nomor 18, Desember 2010.

Hendra Wahanu Prabandani, Rekonstruksi Mekanisme Perencanaan Pembentukan Peraturan Pemerintah Dan Peraturan Presiden di Indonesia, Undang: Jurnal Hukum, Volume 1, Nomor 1, Juni 2018.

Ibnu Sina Chandranegara, Bentuk-Bentuk Perampingan dan Harmonisasi Regulasi, Jurnal Hukum Ius Quia Iustum, Volume 26, Nomor 3, September 2019.

Ibnu Sina Chandranegara, Menemukan Formulasi Diet Regulasi, dalam Prosiding Konferensi Nasional Hukum Tata Negara Ke-4: Penataan Regulasi di Indonesia, Jember, Universitas Jember, 2017.

Jimmy Z Usfunan, Lembaga Pembentuk Perundang-Undangan Di Luar Kementerian, Efektifkah?, dalam Prosiding Forum Akademik Kebijakan Reformasi Regulasi 2019: Menggagas Arah Kebijakan Reformasi Regulasi di Indonesia, Jakarta, Yayasan Studi Hukum dan Kebijakan Indonesia, 2019.

Khairul Fahmi, Otonomi Daerah dalam Ancaman Resentralisasi Pembentukan Peraturan Perundang-Undangan, dalam Prosiding Forum Akademik Kebijakan Reformasi Regulasi 2019: Menggagas Arah Kebijakan Reformasi Regulasi di Indonesia, Jakarta, Yayasan Studi Hukum dan Kebijakan Indonesia, 2019. 
Leo Agustino, Pembatalan 3.143 Peraturan Daerah: Satu Analisis Singkat, CosmoGov: Jurnal Ilmu Pemerintahan, Volume 3, Nomor 1, April 2017.

M. Nur Sholikin, Penataan Kelembagaan Untuk Menjalankan Reformasi Regulasi Di Indonesia, Jurnal Hukum dan Pasar Modal, Volume VIII, Nomor 15, 2018.

Oce Madril, Pembentukan Lembaga Regulasi Nasional Sebagai Upaya Reformasi Regulasi, dalam Prosiding Forum Akademik Kebijakan Reformasi Regulasi 2019: Menggagas Arah Kebijakan Reformasi Regulasi di Indonesia, Jakarta, Yayasan Studi Hukum dan Kebijakan Indonesia, 2019.

Pusat Studi Hukum dan Kebijakan Indonesia, Prosiding Forum Akademik Kebijakan Reformasi Regulasi 2019: Menggagas Arah Kebijakan Reformasi Regulasi di Indonesia, Jakarta, Yayasan Studi Hukum dan Kebijakan Indonesia, 2019.

Richard Susskind, Legal Informatics - a Personal Appraisal of Context and Progress." European Journal of Law and Technology, Volume 1, Nomor 1, Juni 2010.

\section{Makalah:}

Hendra Nurtjahjo, Makalah berjudul "Lembaga, Badan, dan Komisi Negara Independen (State Auxiliary Agencies) di Indonesia: Tinjauan Hukum Tata Negara," disampaikan dalam Diskusi terbatas tentang Kelembagaan Independen di Indonesia yang diselenggarakan oleh Lembaga Administrasi Negara RI, Jakarta, 2005.

Jonathan B. Wiener, Makalah berjudul "Issues in the Comparison of Regulatory Oversight Bodies," disampaikan pada OECD Working Party in Paris, France, 21-22 Oktober 2008.

Kim Song June and Dae Yong Choi, Regulatory Coherence: The Case of the Republic of Korea, ERIA Discussion Paper Series, Nomor 2016-15, Maret 2016.

\section{Skripsi:}

Rilo Pambudi. S, Konstruksi Lembaga Tunggal Pengelola Regulasi di Indonesia, Skripsi, Universitas Maritim Raja Ali Haji, 2020.

\section{Peraturan Perundang-undangan:}

Undang-Undang Dasar Negara Republik Indonesia Tahun 1945.

Undang-Undang Nomor 39 Tahun 2008 Tentang Kementerian Negara, Lembaran Negara RI Tahun 2008 Nomor 166, Tambahan Lembaran Negara RI Nomor 4916.

Undang-Undang Nomor 12 Tahun 2011 Tentang Pembentukan Peraturan Perundang-undangan, Lembaran Negara RI Tahun 2011 Nomor 82, Tambahan Lembaran Negara RI Nomor 5234

Undang-Undang Nomor 15 Tahun 2019 Tentang Perubahan Atas Undang-Undang Nomor 12 Tahun 2011 Tentang Pembentukan Peraturan Perundangundangan, Lembaran Negara RI Tahun 2019 Nomor 183, Tambahan Lembaran Negara RI Nomor 6398.

Peraturan Presiden Nomor 55 Tahun 2020 Tentang Sekretariat Kabinet, Lembaran Negara RI Tahun 2020 Nomor 95. 


\section{Koran:}

Saldi Isra, Merampingkan Regulasi, Jakarta, Koran Kompas, 2017.

\section{Situs Daring:}

https://nasional.kompas.com/read/2019/01/17/21041881/atasi-tumpangtindih-regulasi-jokowi-akan-bentuk-pusat-legislasi-nasional, diakses 27 April 2021.

http://peraturan.go.id, diakses 27 April 2021.

https://pshk.or.id/rr/menagih-janji-jokowi-membentuk-badan-legislasipemerintahan/, diakses 27 April 2021.

https://www.hukumonline.com/berita/baca/lt59f13bb6e2702/akui-kualitasproduk-legislasi-rendah--pemerintah-fokus-harmonisasi-regulasi\%0D, diakses 27 April 2021.

https://www.theglobaleconomy.com/South-Korea/wb_regulatory_quality/, diakses 6 Juni 2020.

http://www3.weforum.org/docs/WEF_TheGlobalCompetitivenessReport2019.pd f, diunduh 1 Juni 2020. 